\title{
PEER COLLABORATION AND SHAC METHODOLOGY IN ENGLISH LANGUAGE CLASSROOM ADOPTING THE FLIPPED LEARNING
}

\author{
BOUALI Assya \\ Dr. Mohammed First University, MOROCCO, assay.bouali@gmail.com
}

\begin{abstract}
Flipped Learning, an approach to teaching and learning, seems to respond to the 21 st century educational standards and meet its requirements.

This mode of instruction has known a rapid and constant growth across the globe. The SHAC methodology (Share Help Ask Comment) within this mode of instruction seems to improve and increase the collaboration processes among students through classroom and online activities. Therefore, the purpose of this research study was to inquire upon students' lived experiences of SHAC methodology in flipped learning context. This research was held using interviews, surveys and class observations of English Language Students in a private Language School that adopts flipped learning mode of instruction. Findings of this research depict that most of the students have sharply developed their interaction, increased their engagement and boosted their collaboration skills. These latter have helped in transforming students from being a mere consumers to knowledge and ideas producers.
\end{abstract}

Keywords: Flipped learning, SHAC Methodology, Collaboration, Language.

\section{INTRODUCTION}

Integrating new technologies in the educational arena has been one of the most striking issues that have grabbed a substantial contemplation in recent decades. Scholars and advocates who work in the expanding field of education assert unanimously that its benefits are countless and limitless. Yet, technology alone cannot help in bettering the educational system unless other key factors also contribute including but not limited to: teachers continual professional development, teaching methodologies and approaches, curriculums and schools infrastructure. Technology should be regarded as one instrument among many others that can be used to help students in their learning process and meet their individual needs and expectations. As a matter of fact, today's learners are digital natives, they have grown up using technology and having access to internet, social media and myriads of other resources. Therefore, Flipped Learning could be hailed as a mode of instruction that responds to teachers' questions and meets students' individual needs.

The organisation of the article will first provide a general overview on flipped learning in general and SHAC methodology in particular, dealing with its backgrounds and conceptual framework. It moves on to address how students' developed their interaction and boosted their collaboration skills.

\subsection{REVIEW OF LITERATURE}

The flipped learning is a recent model of teaching and learning implemented in the educational arena. It is a 
way that is transforming the paradigm of traditional teaching, and replacing it by this innovative and studentcentered way of teaching and learning. Alvarez (2012), Bergmann \& Sams (2012), Berrett (2012), Brunsell \& Horejsi (2011) argued that the flipped classroom is a relatively new way of teaching that involves flipping the traditional approach of classroom instruction. Flipped learning is defined as: "a pedagogical approach in which direct instruction moves from the group learning space to the individual learning space, and the resulting group space is transformed into a dynamic, interactive learning environment where the educator guides students as they apply concepts and engage creatively in the subject matter". (Flipped learning Network, 2012, p.1).

\subsubsection{Flipped Learning Essentials}

Flipped Learning cannot take place unless four pillars are to be incorporated in the practice of teachers. According to Flipped Learning Network (2014: 2) flipping the learning requires the following four pillars to be implemented F-L-I-P (Flexible Environment; Learning Culture; Intentional Content; and Professional Educator).

Flexible Environment requires the integration of a variety of learning modes and the rearrangement of the learning spaces to support learners in their learning process and to accommodate the lessons to their needs. The first pillar, Flexible Environment, necessitates these three fundamental rules:

1. To establish spaces and time frames that permit students to interact and reflect on their learning as needed.

2. To continually observe and monitor students to make adjustments as appropriate.

3. To provide students with different ways to learn content and demonstrate mastery.

Learning Culture is the second pillar of flipped learning. This has to do with shifting the interest towards students and make of them the center of the learning process. This helps in creating an interactive environment where learners have plenty of opportunities to interact, participate in discussions and evaluate their learning in a way that allows them to self-reflect and make the learning more meaningful and personalized. This pillar also requires two rules to be successfully applied in flipped learning model.

1. To give students opportunities to engage in meaningful activities without the teacher being central.

2. To scaffold these activities and make them accessible to all students through differentiation and feedback.

Intentional Content deals with how educators continually make research and think of ways to help students develop conceptual understanding, as well as procedural fluency. They choose materials with meticulous care while being attentive to details onto what students learn and how they learn it. Intentional Content is meant to maximize classroom time in order to adopt methods of student-centeredness, active learning strategies, depending on grade level and subject matter. The three rules that this pillar depends upon are:

1. To prioritize concepts used in direct instruction for learners to access on their own.

2. To create and/or curate relevant content (typically videos) for students.

3. To differentiate to make content accessible and relevant to all students.

Professional Educator is the last pillar upon which flipped learning is founded. This pillar is of an utmost importance for it is more demanding and challenging. Teachers continually observe their students as they are participating in class activities, providing them with instant and constructive feedback and assessing their work on a regular basis. Meta-cognition is part and parcel of this stage because teachers become more reflective in their practice, connect with other educators who are also implementing the flipped learning to improve their instruction and to provide constructive criticism for each other. "While Professional Educators take on less visibly prominent roles in a flipped classroom, they remain the essential ingredient that enables Flipped Learning to occur".

This entails that even teachers play the role of a facilitator and a guide. Yet, real learning won't take place unless they are present.

\subsubsection{Flipped Learning and Student's Centeredness}

It goes without saying that Flipped classroom allows for active learning where students are in charge of their own learning. Knewton (2011) stated that teacher's role changes from traditional "sage on the stage" to "Guide on the side". This emphasizes the tremendous shift in teachers' role being that of a guide and a facilitator rather than a provider of knowledge and information. Therefore, the most important role is being 
played by students for they are actively engaged in their learning, interacting with peers, asking problematic questions and making their learning experience meaningful and more interesting.

Student-centred learning is the second component of successful learning environments for there is a shift from teachers being on stage to students taking in this role. Previously, the classroom environment was dominant by teachers being in the center of the teaching-learning process; they either lectured or gave presentations. Despite the fact that teachers presented very well, students can still be disengaged and lose interests in learning. "Even when this done well, there are often some students who are disengaged from the learning process" (Bergmann \& Sams, 2014: 8). In flipped learning model, this philosophy has disappeared for the paradigm has shifted towards putting much emphasis on the learners rather than on teachers. Bergmann \& Sams (2014: 8) argued that "We observe that when the teacher steps off the stage and becomes a facilitator of learning, rather than a presenter of content, the classroom becomes a center for learning where the focus of the classroom is on the student". Thus, class time is kept for students interacting, engaging in hands-on activities either in groups or in pairs and take charge of their own learning. Rajesh (2015: 56) quoted in (Basal, 2015) that in flipped learning model, students have a great variety of hands on activities, promoting more meaningful learning. This can be done having students watch instructional content before coming to class. Teachers "...can deliver this instruction by recording and narrating screencasts of work they do on their computers, creating videos of themselves teaching, or curating video lessons from trusted Internet sites" (Hamdan et al. 2013). Allowing learners more time to engage in hands on activities cannot be achieved unless learners watch content beforehand in order for them to be active in classroom activities.

Bergmann \& Sams (2014: 8) highlighted some founding principles for optimized learning space to occur:

The creation of collaborative spaces which deals with the fact that students need to have spaces where they can collaborate with each other and make the learning process more meaningful and engaging. "Flipped learning is inherently a collaborative endeavor, and we encourage flipped learning teachers to arrange furniture in ways that encourage collaboration". (Bergmann \& Sams, 2014: 9).

Emphasize student-centeredness of the class is one of the fundamental principles of flipped learning model in general. Thus, creating suitable environments for a better learning opportunities while having student in the focus of the learning space. However, this does not entail by any account that once students are in charge of their learning process, teachers will be passive and become lazier. Teachers' role now has shifted from lecturing to monitoring, circulating around the classroom, providing help as much as needed, and ultimately giving instant and constructive feedback to students. (Bergmann, 2014: 9) "We know teachers who have gone so far as to get rid of their teacher desk. This has forced them to be up and about, working with students".

\subsubsection{Peer Collaboration and SHAC Methodology}

Peer collaboration and SHAC methodology have transformed students' from mere idea consumers to idea producers.

Peer Collaboration refers to how students learn from each other, collaborate and cooperate together either in pairs or groups.

The SHAC refers to the different activities students do when they interact with each other; these include sharing knowledge and information; Helping their classmates when they are stuck and are in need of help; Asking mystifying questions and looking for answers from different perspectives; and finally commenting on important and significant topics, while expressing their minds and evincing their opinions. Therefore, Flipped learning revolves around the idea that students receive video lectures before a lesson and the classroom time is spent on doing SHAC activities. These latter allow for more important tasks and activities that are engaging for students such as discussion of concepts, answering mystifying questions and clarifying complex or hard-to-understand information and content. This atmosphere allows for more active and engaging learning environment. Such classroom environment and activities free up class time for teachers and presents learning choices to students rather than just informing them in a sit-and-listen format. (Chickering \& Gamson; 1986: 2). This entails that when students are studying in a classroom where they are asked to learn on their own and be responsible of their learning process, they become more stimulated and engaged.

\section{METHODOLOGY}

This study is conducted over advanced and intermediate classes in a language school in north eastern 
Morocco. Students do the pre-class activities that prepare them to participate fully in the classroom activities while the class-time is invested in doing the SHAC activities (Share, Help, Ask, Comment). Thus, this research inquires upon students' perception of this innovative approach to teaching and learning the English language.

The data collection of this research study included three different methods, spoken; observed and written. The spoken data comprehended one-to-one and focus group interviews that respond to targeted questions related to the research questions and the purpose of the study. The observed data to be employed in this study was direct non-participant semi-structured observations using fieldnotes. As far as the written data is concerned, open-ended surveys were administered to students using the software 'Survey Monkey' and analyzed using graphs and diagrams.

\section{RESULTS}

\subsubsection{Results of Interviews}

Interaction and Cooperative Learning refers to a form of collaborative learning among students. Students enter in a cooperative relationship and start building their knowledge in a team. This theme was divided into two main subthemes with no additional imbedded themes. Peer Collaboration and SHAC activities. This was advanced across the fifteen sources with no exception. Students expressed their appreciation and the added value of interaction and cooperation in their learning processes. Students were conscious and highly aware of the fruitful benefits interaction can have on improving their English level.

Peer Collaboration was regarded as an indispensable part of students' learning processes. They claimed that through peer collaboration, students have developed self-confidence and have transcended issues of shyness and low self-esteem. Students have also developed their language proficiency and have become fluent in English.

The SHAC refers to four key components of interaction and cooperative learning including Share; Help; Ask; and Comment. Students share their opinions about updated and current issues, they provide the necessary help and aid to each other; Students also raise questions and concerns about the things they find questionable and look for answers from either their peers or the teacher. They can then comment and evince their viewpoints. This subtheme was brought about by the majority of participants and they have emphasized its utmost importance.

\subsubsection{Analyzing Observed Data}

Preparing and organizing the observed data were the two most important elements that were employed. Given the fact that through observations large amounts of data were generated, a decision was made as to follow the framework suggested by (Schensul et al., 1999) in which they referred to this period as "'housekeeping': a systematic tiding up of data". This simply entails that organizing the data is of an utmost importance because it makes the data more manageable and easy to retrieve and to correlate it to the purpose of study. This organization and management of the data also helps in writing up as many examples as possible that support a claim or an interpretation.

In order to organize the data, fieldnotes were filed according to the themes and topics being investigated. In this study, Topical files were the ones utilized. These include Active/cooperative learning; teachers' role; students' engagement \& in-class activities;

In the section below; the themes, categories, subcategories and codes are presented in the form of tables. 
Figure 1. Dimensionalized categories of Interaction and Cooperative learning (SHAC)

\begin{tabular}{|c|c|c|c|c|}
\hline $\begin{array}{c}\text { Global } \\
\text { category } \\
\text { Peer } \\
\text { Collaboration }\end{array}$ & Subcategories & properties & $\begin{array}{l}\text { Dimensional } \\
\text { range }\end{array}$ & Description \\
\hline Code & Sharing & $\begin{array}{l}\text { Frequency } \\
\text { Extent } \\
\text { Intensity } \\
\text { Range } \\
\text { Duration }\end{array}$ & $\begin{array}{l}\text { Often } \\
\text { More } \\
\text { High } \\
\text { Across broad } \\
\text { range of } \\
\text { activities } \\
\text { Ordinate time }\end{array}$ & $\begin{array}{l}\text { - In groups of four: Students share } \\
\text { what they have learnt from the } \\
\text { movie; } \\
\text { - Students switch partners to have } \\
\text { access to different } \\
\text { opinions and viewpoints. } \\
\text { - This activity lasted for } 30 \text { minutes. }\end{array}$ \\
\hline Code & Helping & $\begin{array}{l}\text { Frequency } \\
\text { Extent } \\
\text { Intensity } \\
\text { Range } \\
\text { Duration }\end{array}$ & $\begin{array}{l}\text { Often } \\
\text { More } \\
\text { Average } \\
\text { Across a range } \\
\text { of activities. } \\
\text { Ordinate time }\end{array}$ & $\begin{array}{l}\text { - Students help each other as much } \\
\text { as needed. } \\
\text { - High level students are grouped } \\
\text { with students having difficulties in } \\
\text { understanding to provide help. } \\
\text { - Lasted for } 15 \text { minutes }\end{array}$ \\
\hline Code & Asking & $\begin{array}{l}\text { Frequency } \\
\text { Extent } \\
\text { Intensity } \\
\text { Range } \\
\text { Duration }\end{array}$ & $\begin{array}{l}\text { Often } \\
\text { More } \\
\text { High } \\
\text { Across a range } \\
\text { of activities } \\
\text { Average time }\end{array}$ & $\begin{array}{l}\text { - In pairs, students ask questions } \\
\text { related to the topic and the content of } \\
\text { the movie. } \\
\text { - Lasted for } 15 \text { minutes }\end{array}$ \\
\hline Code & Commenting & $\begin{array}{l}\text { Frequency } \\
\text { Extent } \\
\text { Intensity } \\
\text { Range } \\
\text { Duration }\end{array}$ & $\begin{array}{l}\text { Often } \\
\text { More } \\
\text { High } \\
\text { In all activities } \\
\text { Average }\end{array}$ & $\begin{array}{l}\text { - Students comment on every single } \\
\text { thing they do. They commented on } \\
\text { the documentary; picture and the } \\
\text { quote suggested by the teacher. } \\
\text { - Students are highly encouraged to } \\
\text { comment and give their personal } \\
\text { opinions. } \\
\text { - Commenting is emphasized and } \\
\text { takes } 5 \text { minutes of each activity. }\end{array}$ \\
\hline
\end{tabular}

\subsubsection{Results of Observed Data}

Indeed, these categories were of great avail in that they provided a basis for developing relationships between categories and subcategories on the basis of which it was possible to make sense of what was going on and how it was going on. They also served as a basis for advancing explanations and understandings. By the same token, a mere description of classes would never do what the open coding can do.

Identifying properties of categories and the dimensions of these categories, finest level of analyzing the data could be reached. These latter helped in forming the basis for identifying and developing relationships among categories and contributed in directly advancing explanations and the production of interpretations.

Analyzing the properties of each theme, category and subcategory, it appears that in terms of the first 
general theme, cooperative learning, students learn in a cooperative and collaborative way. The properties and dimensions of this particular category, interaction, and the subcategories including sharing, helping, asking, commenting, checking and comparing, were all the same in terms of frequency, extent, intensity, and range. Therefore, cooperative learning was highly emphasized and formed one of the bedrocks and fundamental aspects upon which these classes are built.

From the look at the table, it can be noticeable that students' interaction, discussions and collaboration is of high use. Students were, with no exception, discussing, evincing their viewpoints, and were thoroughly engaged in discussions, using gestures and facial expressions. Besides, students were listening actively and carefully to their partners' opinions and claims. They commented also whenever they noticed something that attracted or seemed appealing to them.

Furthermore, the atmosphere, the variety of activities and teachers' guidance are all important factors in increasing students' motivation to learn English. Students feel encouraged to speak their minds and have their opinions respected no matter what.

All in all, based on the analysis of the tables above, it can be insinuated that the classes observed depict the effective use of flipped learning, whereby class time is invested in deep and meaningful learning. It also outlines that there is a move from teacher centeredness to students' centeredness. In other words, students are the main actors of the classroom, they learn actively and cooperatively. They are highly engaged in all the activities suggested and try their hardest to make the most out of their learning experiences. The classroom environment, the in-class activities and teachers' role are all important factors that aid in increasing their motivation to learn English and to take their learning by their hands.

\subsubsection{Written Data Analysis}

This study opted for written data collection tool, open ended surveys, as the third method to measure students' perceptions of flipped learning. Therefore, to understand students' perceptions of their lived experiences of this mode of instruction, two surveys were administered to 100 students enrolled in OKE center. An email with each student's individual access link to the survey was sent on January, 16th. But few students filled in these surveys. Another email was sent out by the school principal insisting on students to participate in the survey. This did not seem to bring better results. Hence, despite the fact that the survey was open from the month of January until April, only 49 responses were obtained. On April 12th, the survey was closed and results were being analyzed. This survey included both multiple choice and open ended questions. They were conceived and analyzed using the software 'SurveyMonkey'.

Figure 2. Based on your experience so far, do you think flipped approach promotes interaction and discussion among students?

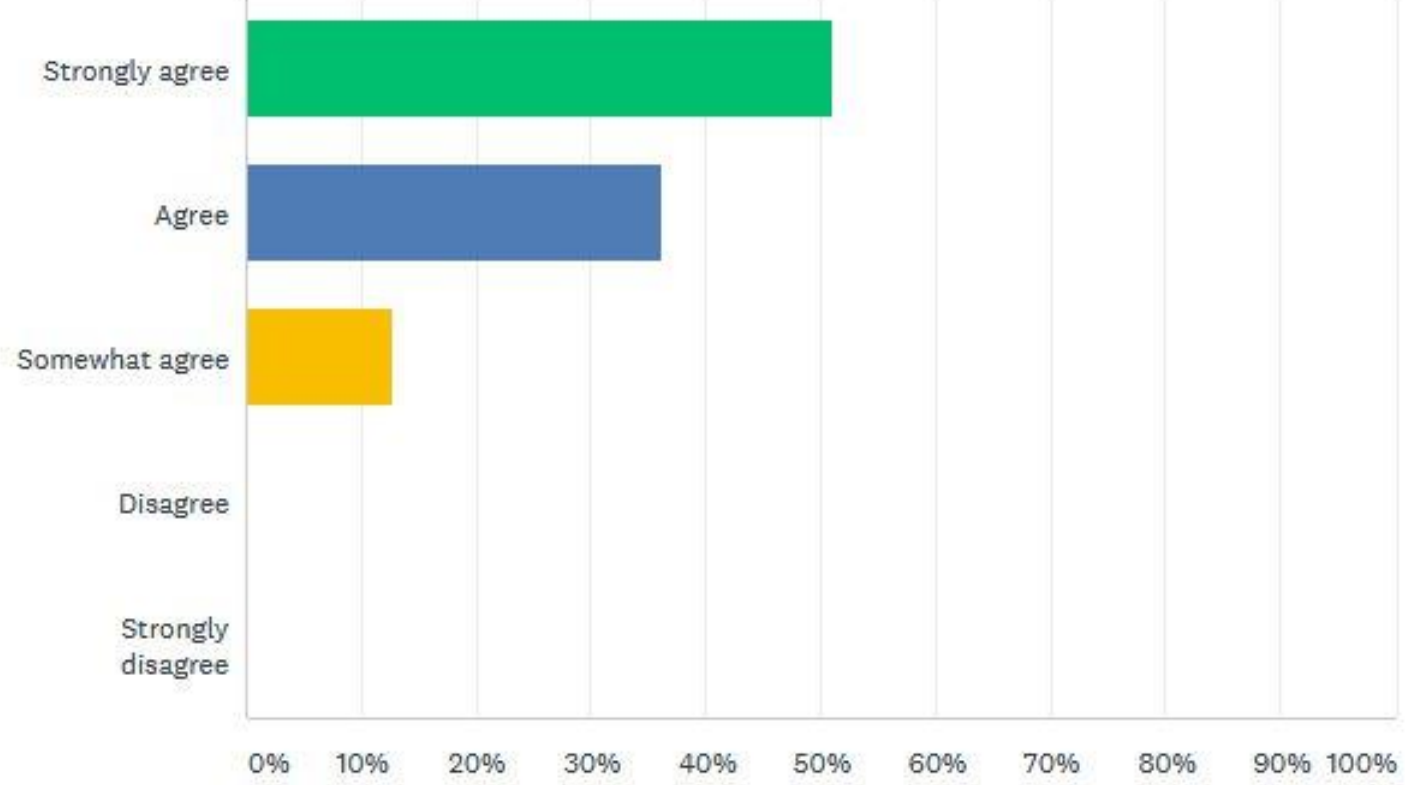

Answers to this question were all positive. Over half the respondents (51\%) strongly agree and (36\%) agree that flipped learning urges interaction and promotes discussion among students in that most of the class time 
is spent on interacting, debating, discussing and exchanging ideas and opinions. Another $12 \%$ of respondents somewhat agreed. The responses to this question outline that one of the fundamental aspects of the classroom flip has been achieved, which is that of investing class time and in-class activities on providing students with ample opportunities of interaction, debate and discussion.

Undoubtedly, students through flipped learning approach have started learning in a way that favors interaction, peer collaboration and cooperative learning activities. Through the SHAC, students could share their thoughts and opinions; they provided help and aid to their peers and classmates whenever they were asked to. Students could also ask questions and get them answered either from their partners or from their teacher. Commenting on the opinions of each other was also emphasized, students were given the opportunity to comment on the things that seemed the most appealing to them and could hear different perspective in return.

In terms of the in class activities, students expressed their tremendous satisfaction of the discussions and the SHAC activities held. Students could hear various comments and viewpoints from different students and this in itself was perceived as an added-value for students can have a general idea on how their peers view the things and based on which evidence and proof they form their opinions. This variety of perspectives facilitated the comparison of ideas and formation of new ideas.

Most of participants' responses emphasized the fact that discussions are better run when students watch videos before, make research and come prepared to class. When students come prepared, they already have some background knowledge to interact effectively and make the discussions more effective, deeper and richer.

In this sense, a student mentioned that "What I like most about the format of flipped class is that how students interact with each other and share their opinions and visions. Equally important, I also like the issues that we deal with, because they are current issues, which can help us in our social life. In other words, we are more open-minded and we are discovering new cultures". Another student thought that "in class activities and discussions make it easier for us to learn, and I like also the fact that we study about global issues".

Students have also reported that the content and choice of the topics are very important. They claimed that when discussing the current issues that are happening around the world, they feel that they are grown up individuals who have a say and who can evince their opinions freely and openly. One student argued that "When you're learning a language the simple and traditional way, you're basically filling your head with words and rules to use them, but you can't tell if you're using them in a correct way. Flipped learning however, encourages you to use what you've acquired from your lessons, in reality, which makes for a great practice since you're taught to use your knowledge for its purpose, and even employ it so as to create solutions for obstacles that face you. Flipped learning teaches you not to learn a language, but to speak it".

Furthermore, respondents also brought about the forming of groups. They were satisfied because students did not have to speak and interact with the same people. They were asked to shift partners each now and then, which made all the respondents feel happy about it. One student said that "I like it when we are asked to change our partners and to join different group because you can speak to people that you don't know and not just to your friends". Another one thought that "I like when the teacher pushes us to change our pairs because at first I was shy and couldn't speak to other students but now I can speak with different students even if I don't know them. Here, the important thing is sharing information, debating and discussing which is just great!"

Indeed, this allows students not only to transcend their fear of speaking to other peers or the obstacle of shyness but they can also have an idea on different perspectives "I like to change the group to see how my friends view the world and if their opinions are similar or different from mine", said one student.

However, some respondents stated some of the drawbacks that, according to them, make them hate the model of flipped learning. Students expressed their dislike especially when students come unprepared to class. This impeded them from doing the SHAC activities effectively. They felt that the discussions become empty and useless. This could lead to repetitive comments from different students trying to help those who did not do the out of class activities or did not watch the videos. According to some students "What I really dislike is that some students don't take seriously the out of class activities, which is an obstacle for the others who do the SHAC with students who have no idea". Within the same perspective, another student asserted that "I don't dislike flipped class but I hate when some lazy students don't do their work and make us lose time and efforts in re-explaining the things to them". 
As far as the possibilities of improving the flipped class, all the respondents were extremely contented and have expressed their full satisfaction. Comments were in the form of short phrases such as "Nothing to add"; "It doesn't have to change, it is very good the way it is"; "I don't have a suggestion to offer", "there is nothing to change", "nothing in particular", "I think flipped learning is perfect", "I think that everything is ok. So, I don't have a suggestion for change in the flipped course format".

However, two of the respondents offered two suggestions to improve the flipped learning class. The first one stated that "if I had the chance to offer one suggestion for change it would be to give more time for the grammar lessons". And another one suggested that "More time for doing the work that mean that the deadline must be longer and that in class activities need to be longer". Therefore, it appeared that one student preferred teachers' involvement in the classroom especially when it comes to grammar lessons. While the second student expressed his need to have in class activities better pace so that students will not have to rush when giving their opinions and so that they can take their time in forming their ideas. This could probably stimulate what is referred to as "not-well-thought-out" that may confuse students and start jumping from one point to another without full grasp of the content.

\section{CONCLUSION}

In a nutshell, it can be deduced that Based on students' comments and answers, it seemed that these students upon which the study was conducted, achieved better learning outcomes, increased their motivation and devotion to learn English, and most importantly, they developed better attitudes towards learning English in general. Students' satisfaction increased and held a positive attitude towards the teaching and learning activities. They perceive their experiences of flipped learning as stimulating and engaging. Students are especially satisfied and happy with the in class activities and SHAC methodology because it is the place where their creativity thrives. They have fun and feel that they are the center of the classroom.

\section{REFERENCE LIST}

Abbott, C. (2007). E-inclusion: Learning difficulties and digital technologies (Vol. 15): Futurelab Bristol.

Abeysekera, L., \& Dawson, P. (2015). Motivation and cognitive load in the flipped classroom: definition, rationale and a call for research. Higher Education Research \& Development, 34(1), 1-14.

Akbari, E., Naderi, A., Simons, R.-J., \& Pilot, A. (2016). Student engagement and foreign language learning through online social networks. Asian-Pacific Journal of Second and Foreign Language Education, 1(1), 4.

Alsowat, H. (2016). An EFL Flipped Classroom Teaching Model: Effects on English Language Higher-Order Thinking Skills, Student Engagement and Satisfaction. Journal of Education and Practice, 7(9), 108121.

Anderson, L. W., Krathwohl, D. R., Airasian, P. W., Cruikshank, K. A., Mayer, R. E., Pintrich, P. R.,... Wittrock, M. C. (2001). A taxonomy for learning, teaching, and assessing: A revision of Bloom's taxonomy of educational objectives, abridged edition. White Plains, NY: Longman.

Anderson, R., Davis, P., Linnell, N., Prince, C., Razmo, V., \& Videon, F. (2007). Classroom presenter: Enhancing interactive education with digital ink. Computer, 40(9).

Anderson, R. C., \& Pearson, P. D. (1984). A schema-theoretic view of basic processes in reading comprehension. Handbook of reading research, 1, 255-291.

Anney, V. N. (2014). Ensuring the quality of the findings of qualitative research: Looking at trustworthiness criteria.

Anthony, E. M. (1963). Approach, method and technique. English language teaching, 17(2), 63-67.

Archambault, L., Wetzel, K., Foulger, T. S., \& Kim Williams, M. (2010). Professional development 2.0: Transforming teacher education pedagogy with 21 st century tools. Journal of Digital Learning in Teacher Education, 27(1), 4-11.

Basal, A. (2015). The implementation of a flipped classroom in foreign language teaching. Turkish Online Journal of Distance Education, 16(4), 28-37. 
Baytak, A., Tarman, B., \& Ayas, C. (2011). Experiencing technology integration in education: children's perceptions. International Electronic Journal of Elementary Education, 3(2), 139.

Begum, M. (2014). Attaining Motivation and Learner Autonomy to Encourage Independent Study. Language in India, 14(11).

Bennett, B., Spencer, D., Bergmann, J., Cockrum, T., Musallam, R., Sams, A.,... Overmyer, J. (2012). The flipped class manifest. The Daily Riff.

Benson, P. (2007). Autonomy in language teaching and learning. Language teaching, 40(1), 21-40.

Benson, P., \& Voller, P. (2014). Autonomy and independence in language learning: Routledge.

Bergmann, J., Overmyer, J., \& Wilie, B. (2015). The Flipped Class: Myths vs. Reality-THE DAILY RIFF-Be Smarter. About Education. Thedailyriff. com: Retrieved.

Bergmann, J., \& Sams, A. (2012). Flip your classroom: Reach every student in every class every day: International Society for Technology in Education.

Bergmann, J., \& Sams, A. (2014). Flipped learning: Gateway to student engagement: International Society for Technology in Education.

Berrett, D. (2012). How'flipping'the classroom can improve the traditional lecture. The Education Digest, 78(1), 36

Best, J. R., Miller, P. H., \& Naglieri, J. A. (2011). Relations between executive function and academic achievement from ages 5 to 17 in a large, representative national sample. Learning and individual differences, 21(4), 327-336.

Bishop, J. L., \& Verleger, M. A. (2013). The flipped classroom: A survey of the research. Paper presented at the ASEE National Conference Proceedings, Atlanta, GA.

Borg, M. O., \& Shapiro, S. L. (1996). Personality type and student performance in principles of economics. The Journal of Economic Education, 27(1), 3-25.

Bormann, J. (2014). Affordances of flipped learning and its effects on student engagement and achievement.

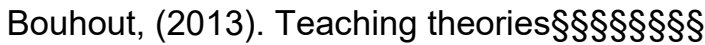

Brewer, D. S. (2009). The effects of online homework on achievement and self-efficacy of college algebra students: Utah State University.

Brewer, R., \& Movahedazarhouligh, S. (2018). Successful stories and conflicts: A literature review on the effectiveness of flipped learning in higher education. Journal of Computer Assisted Learning.

Broussard, S. C., \& Garrison, M. (2004). The relationship between classroom motivation and academic achievement in elementary-school-aged children. Family and Consumer Sciences Research Journal, 33(2), 106-120.

Brown, J. D. (1988). Understanding research in second language learning: A teacher's guide to statistics and research design: Cambridge University Press.

Brunsell, E., \& Horejsi, M. (2011). Science 2.0: Using web tools to support learning. The Science Teacher, 10.

Chaiklin, S. (2003). The zone of proximal development in Vygotsky's analysis of learning and instruction. Vygotsky's educational theory in cultural context, 1, 39-64.

Cohen, A. D., \& Dörnyei, Z. (2002). Focus on the language learner: Motivation, styles, and strategies. An introduction to applied linguistics, 170-190.

Cook, T. D., \& Reichardt, C. S. (1979). Qualitative and quantitative methods in evaluation.

Hammond, J. (2001). Scaffolding: Teaching and Learning in Language and Literacy Education: ERIC.

Hammond, J., \& Gibbons, P. (2005). Putting scaffolding to work: The contribution of scaffolding in articulating ESL education.

Harmer, A. J., \& Cates, W. M. (2007). Designing for learner engagement in middle school science: Technology, inquiry, and the hierarchies of engagement. Computers in the Schools, 24(1-2), 105-124. 
Network, F. L. (2012). Improve student learning and teacher satisfaction with one flip of the classroom. Retrieved from author http://flippedlearning1. files. wordpress. com/2012, 7.

Network, F. L. (2014). The four pillars of FLIP.

Newton, K., \& Zmerli, S. (2011). Three forms of trust and their association. European Political Science Review, 3(2), 169-200.

Nixon, B., \& Ronson, F. Ausubel, 1986. Two component regulating systems responsive to environmental stimuli share strongly conserved domains with the nitrogen assimilation regulatory genes ntrB and ntrC. Proc. Natl. Acad. Sci. USA, 83, 7850-7854.

Nunan, D. (1987). Communicative language teaching: Making it work. ELT journal, 41(2), 136-145.

Nunan, D. (1989). Designing tasks for the communicative classroom: Cambridge University Press.

Pascarella, E. T., \& Terenzini, P. T. (2005). How college affects students: Vol. 2 A decade of research: San Francisco: John Wiley \& Sons, Inc.

Perry, C. A. (2011). Motivation and attitude of preservice elementary teachers toward mathematics. School Science and Mathematics, 111(1), 2-10.

Pierce, R., \& Fox, J. (2012). Vodcasts and active-learning exercises in a "flipped classroom" model of a renal pharmacotherapy module. American journal of pharmaceutical education, 76(10), 196.

Plass, J. L., Moreno, R., \& Brünken, R. (2010). Cognitive load theory: Cambridge University Press.

Richards Jack, C., \& Rodgers Theodore, S. (1986). Approaches and Methods in Language Teaching. Journal of Women s Health.

Roehl, A., Reddy, S. L., \& Shannon, G. J. (2013). The flipped classroom: An opportunity to engage millennial students through active learning. Journal of Family and Consumer Sciences, 105(2), 44.

Rogoff, B. (2008). Observing sociocultural activity on three planes: Participatory appropriation, guided participation, and apprenticeship. Pedagogy and practice: Culture and identities, 58-74.

Rosenberg, J., Lorenzo, M., \& Mazur, E. (2006). Peer instruction: Making science engaging. Handbook of college science teaching, 77-85.

Skehan, P. (1996). A framework for the implementation of task-based instruction. Applied linguistics, 17(1), 38-62.

Skehan, P. (1998). Task-based instruction. Annual review of applied linguistics, 18, 268-286.

Spradley, J. P., \& McCurdy, D. W. (1980). Anthropology, the cultural perspective: John Wiley \& Sons.

Stipek, D. J. (1996). Motivation and instruction. Handbook of educational psychology, 85-113.

Stoddard, A., Harmer, A., Haver, K., Salomons, D., \& Wheeler, V. (2007). Cluster approach evaluation: Final draft. Geneva: IASC, 5.

Strauss, A., \& Corbin, J. M. (1990). Basics of qualitative research: Grounded theory procedures and techniques: Sage Publications, Inc.

Strayer, J. (2007). The effects of the classroom flip on the learning environment: A comparison of learning activity in a traditional classroom and a flip classroom that used an intelligent tutoring system. The Ohio State University.

Strayer, J. (2011). The flipped classroom: Turning the traditional classroom on its head. Knewton website, 8.

Summer, T. (2010). Key Concept: Learner Autonomy.

Swain, M. (1985). Communicative competence: Some roles of comprehensible input and comprehensible output in its development. Input in second language acquisition, 15, 165-179.

Thistlethwaite, J. (2012). Interprofessional education: a review of context, learning and the research agenda. Medical education, 46(1), 58-70.

Thornbury, S. (2006). An aZ of ELT: Oxford: Macmillan.

Torkelson, V. (2012). The flipped classroom, putting learning back into the hands of students: Saint Mary's 
College of California.

Tucker, B. (2012). The flipped classroom. Education next, 12(1).

Van den Branden, K. (2016). Task-based language teaching. The Routledge handbook of English language teaching, 238-251.

Verenikina, I. (2003). Understanding scaffolding and the ZPD in educational research.

Vinson, D., Nixon, S., Walsh, B., Walker, C., Mitchell, E., \& Zaitseva, E. (2010). Investigating the relationship between student engagement and transition. Active Learning in Higher Education, 11(2), 131-143.

Vygotsky, L. (1978). Interaction between learning and development. Readings on the development of children, 23(3), 34-41.

Vygotsky, L. (1987). Zone of proximal development. Mind in society: The development of higher psychological processes, 5291, 157.

Vygotsky, L. S. (1962). Language and thought. Massachusetts Institute of Technology Press, Ontario, Canada.

Wardhaugh, R. (1969). Reading; a linguistic perspective: Harcourt, Brace \& World.

Widdowson, H. G. (1978). Teaching language as communication: Oxford University Press.

William, M., \& Burden, R. (1997). Psychology for language teachers. Cambrdge: Cambridge.

Willis, J. (1994). Task-based language learning as an alternative to PPP. The Teacher Trainer, 8(1).

Willis, J. (1996). A flexible framework for task-based learning. Challenge and change in language teaching, 52-62.

Wilson, K. (1999). Note-taking in the academic writing process of non-native speaker students: Is it important as a process or a product? Journal of College Reading and Learning, 29(2), 166-179.

Wilson, R. (2006). Coleridge and the Life of Language. Coleridge Bulletin, 27, 38-44. .

Yusuff, K. B. (2018). Does personalized goal setting and study planning improve academic performance and perception of learning experience in a developing setting? Journal of Taibah University Medical Sciences.

Zimmerman, B. J. (1989). A social cognitive view of self-regulated academic learning. Journal of educational psychology, 81(3), 329. 